\title{
The McDonaldization of Higher Education?: Notes on the UK Experience
}

\author{
Christian Garland
}

\begin{abstract}
"But if we probe a little deeper, we discover that despite all these manifestations, man's way of thinking and acting is not progressing as much as one might be led to believe. On the contrary, the principles now underlying the actions of men, at least in a large portion of the world, are certainly more mechanical than in other periods when they were grounded in living consciousness and conviction. Technological progress has helped to make it even easier to cement old illusions more firmly, and to introduce new ones into the minds of men without interference from reason." Max Horkheimer The Social Tasks of Philosophy [1]
\end{abstract}

The title of these 'notes' is of course an allusion to The U.S. sociologist George Ritzer's thesis of 'The Mcdonaldization of Society' in which he puts forward the theory of an ever more instrumentally rationalized labour process mirrored in an equally instrumentalized sphere of consumer 'choices' essentially already made, so that standardization and 'efficiency' become the unifying functional paradigm for society as a whole. In applying such a theory to higher education, there is intended a deliberate provocation aimed at contributing to critical debates on the substance and purpose of the university, and that over-used but misrepresented concept, 'knowledge'. Ritzer theorizes from what has been described as a neo-Weberian standpoint to analyse the social processes he identifies in four essential aspects as 'McDonaldization': efficiency, calculability, predictability, and increased control through the replacement of human labor with technology.

We can apply these four key concepts to higher education by defining each in this specific context. 'Efficiency' can be seen twofold: as the restructuring of the university toward market-defined goals of 'value' - both in terms of government funding, and to the student 'stakeholder', and of course in terms of the efficient 'production line' of graduates to meet the ever-changing needs of capital, or the 'challenges' of globalization. Such a process of instrumental rationality reduces university education and research to a 'calculable' formula of 'knowledge production' or to use the insipid management-speak term 'knowledge transfer', as if thought were itself merely a quantifiable known-sum to be 'transferred' and managed accordingly. The 'predictability' of the 'McDonaldization' process at work in UK higher education, can be seen in the bureaucratic rationalization of teaching and research to serve straightforwardly economic ends. This can be observed in everything from the squeeze on research funding and subject areas, and the need to attract corporate investment, to the emphasis on 'transferable skills' to be acquired by students by the end of their studies. In critically applying the fourth aspect of Ritzer's thesis to higher education, we can observe this process of instrumental planning and rationalization in the increasing loss of academic autonomy and bureaucratic 'performance assessment', which is of course directly linked to an institution's success in churning out graduates ready and willing for the demands of the so-called 'knowledge economy.'

To restate, however, by employing Ritzer's theory in this specific context it should be made clear that this does not imply unqualified support for his thesis, merely that it can be critically employed in an understanding of the processes at work in UK higher education, and by definition society as a whole.

The 2003 government White Paper by the then Education Secretary Charles Clarke - a man not noted for his belief in the value of thought for its own sake - makes it quite clear that the purpose of UK higher education, indeed all education should be about "harnessing knowledge to wealth creation"[2]; or to translate this Third Way sound bite: universities are - or must at least become - the training centres for cognitive capitalism, in which while an 
increasing majority 'participate', the purpose of such 'participation' is merely to achieve a relative upward re-skilling of the workforce to produce a standardised white-collar product ready for 'the world of work' [3], indeed according to this logic, it is the duty of universities to turn out graduates equipped with the desire and willingness to fight their way to the front of the marathon rat race of survival that is late capitalism. To phrase this in perhaps bolder terms: besides those who will be rewarded with a place on one of the select graduate training programmes for a FTSE 100 company, taking their place in the executive-managerial class, there will also remain a sufficiently compliant, but still more importantly 'motivated' pool of 'knowledge' workers, aware of the shortage of worthwhile jobs, and prepared to accept the diminishing returns they face competing for them. Similarly, the ever-expanding number of routine, badly paid 'service' jobs in and outside the 'information' sector which require little but the ability not to quit, will further increase, exerting a downward effect of de-skilling, thus requiring a continual process of re-training, and 'learning' as a matter of survival.

According to this logic, the university must provide a 'service' in which the student 'consumer' can measure the value of their 'investment' in quantifiable terms: from the 'quality' of the education they receive as measured in RAE and QAA scores to the 'real world' financial pay-off they can look forward to in the long term. The value of education in this sense can be seen as a straightforward instrumental means toward the no less instrumentalized end of improving one's chances in the labor market. Universities must accept the need for "reform" - that is, the reorienting from their original purpose toward training and honing the 'transferable' skills required by the 'knowledge economies' of advanced capitalism.

There is of course the familiar and reactionary counter-argument against the present so-called 'mass-production' of university education, students, and graduates, which sees in any expansion of student numbers or indeed educational institutions, an inevitable 'decline' in the quality of education offered. According to such insipid wisdom, classical 'liberal education' - once embodied in this country solely in the hallowed portals of Oxbridge colleges can and should only ever be the preserve of a few.[4] This argument serves as a useful straw man for the more 'forward thinking' neoliberal strategy behind New Labour's education policy, which can have the appearance of being 'progressive' merely because it proposes 'change', or 'reform' regardless of what this may actually entail. According to such ideological prescriptions, any opposing argument must be 'conservative' or regressive since it is opposed to this version of 'progress', which by its own definition can be the only one: a classic example of Marx's old camera obscura.

In his inaugural address to Universities UK, CBI Director General Richard Lambert, whilst complaining of the oversupply of graduates, also noted, "Skills and employability should be seen as part of the return on the substantial public investment that is already made in the sector. That's why we all pay taxes.' [5] University education and research, therefore, should be about producing 'better skilled' employees and managers ready to meet 'the needs of business.' In the same introduction to the government White Paper, Charles Clarke notes that "reform" of higher education is essential, since "the world is already changing faster than it has ever done before and the pace of change will continue to accelerate.”[6] This is strongly reminiscent of Anthony (Lord) Giddens' admittedly pretty threadbare concept of a 'runaway world' which governments cannot hope to control much less steer, and which unless people face up to, they are in danger of being flattened by: a suitably nebulous post-ideological justification for the neoliberal project, which finds its embodiment par excellence in New Labour and the 'Third Way'.

If we accept the wisdom of both government and industry, "change" rather like "reform" is an objective, external process that happens to us, we cannot (and should not) expect to be able to influence it, much less initiate it. Repeating Marx is always useful, so to restate a paraphrased version of the Theses on Feurbach, the purpose of thought - education and research - is not merely to "interpret" the world - as it exists -but to continually set out to challenge it, and to change it. This is not to pretend that the 'classical' university fulfilled this purpose, but to recognize that the limited extent to which it allowed space for critical thought should be developed and expanded. Such a proposal is necessarily at odds with both the 'future' for higher education in the UK proposed by New Labour, and the reactionary desire to 'restore' the reputation of the classical university by restricting and limiting both access, and the nature of study and research to a narrow list of 'traditional' subjects, deemed to be worthy of scholarly inquiry.

In the same introduction Charles Clarke contends,

"Our national ability to master that process of change and not be ground down by it depends critically upon our universities. Our future success depends upon mobilizing even more effectively the imagination, creativity, skills, and talents of all our people. And it depends on using that knowledge and understanding to build economic strength and social harmony."[7] 
Whilst it is easy to snigger at the Blair-heavy inflection of this rallying cry for national endeavor, it offers a useful summing up of New Labour's belief that education and research must serve straightforwardly instrumental ends, proven by their 'usefulness' in one form or another to 'business' (i.e. capital), or to 'informing policy making' (i.e. as functional to the needs of the state). Indeed, according to such spurious reasoning, "wealth creation" and "economic strength", or the subsumption of life to the law of value, the infernal cycle of capital accumulation, profit and loss, is the only worthwhile goal for not just universities but all human activity. 'Knowledge' in the sense of the 'knowledge economy' is not 'knowledge' at all, if we take this to mean the substantive, critical understanding of something, be it a concept, a theory, or a subject; by contrast instrumentalized knowledge defines and limits thought to within the orbit its of its own predetermined ends. Indeed such instrumental logic in higher education can be seen in a recent study by the LSE's Centre for Economic Performance looking at the employment of UK graduates which found $33.8 \%$ of those from Oxbridge or pre-1992 'research-intensive' universities overqualified for the jobs they found themselves doing. [8] Instrumentalized reason finds an apt expression in a university research centre devoted to the study of 'economic performance', producing a report on the correlation between higher education, subjects studied, career prospects, and earnings - which also concludes,

"Choosing courses with low pecuniary returns is potentially rational and can suit the lifestyle choices of many. A problem only arises if young people are led to expect higher pecuniary returns than subsequently will experience."[9]

The decision to study a subject of interest for its own sake, without an eye toward how it might be of benefit to getting ahead in some future 'career' is only "potentially rational" (sic) if it is accepted that the payoff for such a decision will be a lifetime of debt and precarious, poorly paid employment. The same reasoning is behind Richard Lambert's comment in his inaugural Universities UK speech when he cautions:

"There is a sense, I am afraid, that more means less - that the rapid increase in the number of students graduating from college or university has come at the expense of quality, in terms of knowledge, attitude, and employability. That, surely, is a perception that universities need to be addressing head on."[10]

Such a perspective would seem to favour both a reduction in the number of university places and a further shift towards market-focused imperatives for education and research. However, the similarities between government policy and the position of the CBI's Director-General are greater than might at first appear: New Labour's target of getting 50\% of 18-30 year olds into higher education is not aimed at increasing ease of access to studying or research for its own sake, much less in advancing outdated notions such as social equality, instead a distinctive hierarchy of higher education provision is aimed at, encompassing much of the 'vocational' or 'apprenticeship' type courses called for by 'business', and conservative critics alike. Indeed it is fair to say that a majority of the ' $50 \%$ target' are likely to acquire HNCs, HNDs, Foundation degrees, or for that matter Honors degrees in career-focused vocational fields, which are aimed solely at developing skills for a 'career', obtained from a university regarded as being of minimal prestige: it is these very same qualifications and institutions which are expanding to accommodate increased student numbers, and which Lambert cautions are of limited value, despite calling for increased vocational education. The market imperatives imposed on all universities are felt as elsewhere, by those furthest down the food chain: in this case a large number of ex-polytechnics and HE institutes find their existing resources stretched even further with funding dependent on the sole proviso that they increase the number of students they enroll.

To conclude, we might return to the question of the title of these notes, and ask again how we can usefully apply Ritzer's McDonalidization thesis to UK higher education? McDonalidization can be seen as the tendency toward hyper-rationalization of these same processes, in which each and every task is broken down into its most finite part, and over which the individual performing it has little or no control, becoming all but interchangeable. It may be argued that the labor processes involved in advanced technological capitalism increasingly depend on either the handling and processing of information, or provision of services requiring instrumentalized forms of communication and interaction, just as these same 'professional' roles frequently consist of largely mechanized, functional tasks requiring a minimum of individual input or initiative, let alone creative or critical thought, a process illustrated in blackly comic form by the 1999 film Office Space.

However the same absurd logic of capital demands that as such jobs come to proliferate, the worker, or rather 'professional' should identify with such tedium and feel it to be their own, despite the fact they are more than likely on a temporary contract and could be replaced in a matter of hours. The fact that one has more or less identical 'transferable skills' to apply to a 'career profile' of course creates even more intensive competition for a diminishing 
number of jobs, which paradoxically, demand more or less the same skills until they are rendered obsolete, by a further process of instrumental rationalization. The model of higher education proposed by the present government, is aimed at serving just such a process in which far from 'creating opportunity', "Education becomes not the symbol of our unfinished development, but of our permanent inadequacy.”[11]

\section{Endnotes}

1. Horkheimer, Max The Social Tasks of Philosophy (1939) online version: http://www.marxists.org/ reference/archive/horkheimer/1939/social-function. htm"

2. Clarke, Forward to The Future of Higher Education DFES White Paper (2003) p.2 online version: http:// www.dfes.gov.uk/hegateway/uploads/White\%20Pape. pdf

3. Given the levels of student debt in the UK - pace the claims of the government and the regional Scottish and Welsh administrations, 'the world of work', specifically its worst paid, most exploitative sectors will be something that few students will be unfamiliar with, either during or after their studies.

4. It is also interesting to note, however, that many of the most well-known proponents of this argument - Alan Smithers, Anthony O'Hear, Roger Scruton - have some past or present association with the (private) University of Buckingham, a less than 'prestigious' institution which specializes in two-year vocationally-oriented subjects, with a particular emphasis on business and management studies.

5. Lambert, Inaugural Universities UK Speech 11.12.2007 online version: http://www.cbi.org.uk /ndbs/press.nsf/0363c1f07c6ca12a8025671c00381cc7 /99671dd107d3a624802573ae0051697a?OpenDocum ent

6. Clarke, ibid

7. Clarke, ibid

8. Figure quoted in the Financial Times 24/25.11.2007

9. ibid

10. Lambert, ibid

11. Illich, Ivan and Etienne Verne Imprisoned in the Global Classroom (Writers \& Readers 1976) p.11

\section{References}

The Future of Higher Education. 2003. DFES White Paper online: (http://www.dfes.gov.uk/hegateway/uploads/White\%20Pape. pdf).

Horkheimer, Max. [1939] 1982. The Social Tasks of Philosophy in Critical Theory: Selected Essays. Online version at: (http:// www.marxists.org/reference/archive/horkheimer/1939/social-function.htm).

Illich, Ivan and Etienne Verne. 1976. Imprisoned in the Global Classroom. London: Writers and Readers.

Kellner, Douglas. 1998. Theorizing/Resisting McDonaldization: A Multiperspectivist Approach online version: (http://www. gseis.ucla.edu/faculty/kellner/Illumina\%20Folder/kell30.htm).
Lambert, Richard Inaugural Universities UK Speech delivered 11.12.2007 online version: (http://www.cbi.org.uk/ndbs/ press.nsf/0363c1f07c6ca12a8025671c00381cc7/99671dd107d3a624802573ae0051697a?OpenDocument).

Ritzer, George. 2007. The McDonaldization of Society 5. Thousand Oaks: Pine Forge Press. 